\section{Income inequality and economic residential segregation}

\section{Kawachi}

\section{The relation between income inequality and economic residential segregation is undoubtedly causal}

t is now widely acknowledged that the surge in income inequality in the United States since the mid-1970s was accompanied by a sharp increase in the spatial concentration of poverty. Between 1970 and 1990, the percentage of urban poor Americans living in non-poor neighbourhoods (where less than $20 \%$ of households live below the official poverty threshold) declined from $45 \%$ to $31 \%$, while the percentage living in poor neighbourhoods (poverty rates between $20 \%$ and $40 \%$ ) increased from $38 \%$ to $41 \%{ }^{1}$ At the opposite end of the income distribution, the pattern of residential concentration is even more striking. In 1970, the typical affluent American family-defined as having an income level at least four times the poverty rate-lived in a neighbourhood that was $39 \%$ affluent. By 1990, this had increased to $52 \%$-that is, the typical affluent person lived in a neighbourhood where more than half the residents were also rich. ${ }^{1}$

The connection between income inequality and economic residential segregation is undoubtedly causal. As the rich pull away from the rest of society, they either relocate to areas where other affluent families live, or they tend to bid up the price of local housing. The spiralling costs of housing, in turn, displace families with lower incomes. In the city of San Carlos, for instance, in the heart of the recent Silicon Valley boom, the median house price was $\$ 680000$ in 2000, which forced the mayor to move out because he could no longer afford a home there. ${ }^{2}$ A typical rent for a three bedroom mobile home in the area was reported to be $\$ 1795$ per month. According to a report in the New York Times, many people forced to live in outlying towns leave their homes at 4 am to commute to work in Silicon Valley. Commuting distances of 160 kilometres per day are not uncommon. One commuter, a construction manager, estimated that he spent 2048 hours working in the year 2000, compared with 1100 hours commuting, and 608 hours with his family at home. In other words, he spent twice as many hours driving as he did with his wife and children.

The predictable result of such a lifestyle is burn out, stress, increased alcohol and drug misuse, sleeping problems, and car accidents, not to mention increased pollution and incidents of road rage. Residential segregation can be particularly noxious for poor families who are left behind in neighbourhoods where the tax base has steadily dwindled for financing public education, public transport, and other services and amenities. However, despite these plausible connections between economic residential segregation and health outcomes, few investigators have attempted to link the two. In an analysis of the National Health Interview Survey matched to the $\mathrm{Na}$ tional Death Index, Waitzman and Smith $^{3}$ found that the spatial concentration of poverty was significantly associated with increased risk of mortality for both elderly and non-elderly residents of large urban areas in the United States during the late 1980s and early 1990s. In contrast, the spatial concentration of affluence was only sporadically associated with increased mortality risk among the non-elderly, and consistently associated with lower mortality risk among the elderly. ${ }^{3}$ These findings persisted in the face of control for individual level income.

The paper by Lobmayer and Wilkinson in the current issue of the journal is a welcome addition to this slim literature. ${ }^{4}$ Using data for 276 metropolitan areas of the United States, the authors conclude that: (a) income inequality is related to economic segregation ( $r=0.6)$; and (b) income inequality and residential segregation were each independently associated with mortality. For the very young (under 1 year) and old (over 65 years), residential segregation seemed to partly mediate the association between income inequality and mortality, at least judging by the large attenuation of the regression coefficient for income inequality when seg- regation was introduced into the same models.

These findings raise intriguing questions for future research. If the relation between income inequality and mortality for everyone except the very young and old is not mediated by residential segregation, the search must continue for the mechanisms linking both factors to mortality. Crucial to this search will be the ability of researchers to demonstrate a true contextual effect of both income inequality and residential segregation on individual health outcomes. Multilevel analysis is needed to enable researchers to tease out contextual effects from the compositional effects of poverty concentration in small areas. ${ }^{5}$ To date, nine multilevel studies have been published looking at the effects of income inequality on health outcomes, though most of these examined income inequality at the state level. Three of these nine studies have found no effects, or inconsistent effects of income inequality on health, ${ }^{6-8}$ while the remaining six found a small but independent effect of income inequality even after adjusting for individual level income. ${ }^{9-14}$ For residential segregation, the study by Waitzman and Smith ${ }^{3}$ remains the only one that controlled for individual income.

Finally, it is widely recognised that in the United States, racial/ethnic residential segregation is much more extensive than economic segregation. ${ }^{15}$ Although Lobmayer and Wilkinson ${ }^{4}$ did not specifically investigate the contribution of racial segregation, it is clear that further research should examine the separate and additive contribution of racial segregation on the health effects of both economic segregation and income inequality. ${ }^{16}$

$J$ Epidemiol Community Health 2002;56:165-166

\section{Authors' affiliations}

I Kawachi, Department of Health and Social Behavior, Harvard School of Public Health, 677 Huntington Avenue, Boston, MA 02115 , USA

Correspondence: Dr I Kawachi; Ichiro.Kawachi@channing.harvard.edu

\section{REFERENCES}

1 Massey DS. The age of extremes: concentrated affluence and poverty in the twenty-first century. Demography 1996;33:395-412.

2 New York Times. In the other California, land rush continues. Wednesday, 27 December 2000:A10.

3 Waitzman NR, Smith KR. Separate but lethal: the effects of economic segregation on mortality in metropolitan America. Milbank Memorial Fund Q 1998:76:341-73.

4 Lobmayer P, Wilkinson RG. Inequality, residential segregation by income, and mortality in US cities. J Epidemiol Community Health 2002;56:183-7.

5 Subramanian SV, Kawachi I, Kennedy BP. Does the state you live in make a difference? 
Multilevel analysis of self-rated health in the US. Soc Sci Med 200 1;53:9-19.

6 Daly MC, Duncan GJ, Kaplan GA, et al. Macro to micro links in the relation between income inequality and mortality. Milbank

Memorial Fund Q 1998;76:315-39.

7 Fiscella K, Franks P. Poverty or income inequality as predictor of mortality: longitudinal cohort study. BM

1997;314:1724-7.

8 Mellor JM, Milyo J. Reexamining the evidence of an ecological association between income inequality and health. $J$ Health Politics Policy Law 2001 ;26:487-522.

9 Blakely TA, Lochner K, Kawachi I. Metropolitan area income inequality and self-rated health-a multilevel study. Soc Sci Med 2002;54:65-77.

10 Diez-Roux AV, Link BG, Northridge ME A multilevel analysis of income inequality and cardiovascular disease risk factors. Soc Sci Med 2000;50:673-87.

11 Kahn RS, Wise PH, Kennedy BP, et al. State income inequality, household income, and maternal mental and physical health: cross-sectional national survey. BM 2000;321:1311-15.

12 Kennedy BP, Kawachi I, Glass R, et al. Income distribution, socioeconomic status, and self rated health in the United States: multilevel analysis. BM 1998;317:917-21.
13 Lochner K, Pamuk E, Makuc D, et al. State-level income inequality and individual mortality risk: a prospective, multilevel study. Am J Public Health 2001;91:385-91.

14 Soobader M-J, LeClere F. Aggregation and the measurement of income inequality: Effects on morbidity. Soc Sci. Med 1999;48:733-44.

15 Acevedo Garcia D, Lochner K. Residential segregation and health. In: Kawachi I, Berkman LF, eds. Neighborhoods and health. New York: Oxford University Press (in press).

16 Kawachi I, Kennedy BP, Wilkinson RG. Income inequality and health. New York: The New Press, 1999.

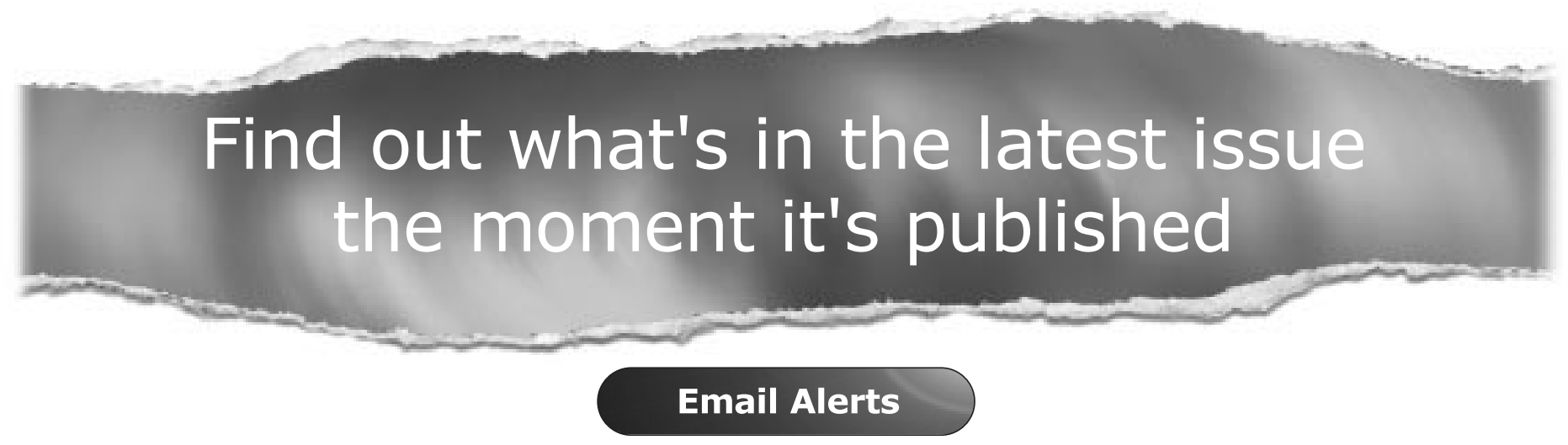

Sign up to receive the table of contents by email every month. You can select from three alerts:

Table of Contents (full), TOC Awareness (notice only); Journal of Epidemiology and Community Health related announcements.

www.jech.com 